\title{
LEGAL POLICY AND ITS POSITION IN THE TAXONOMY OF SCIENCE
}

\author{
Wahju Prijo Djatmiko \\ Doctoral Program of Law, Universitas Diponegoro, Indonesia \\ E-mail: djatmiko.ldwd@gmail.com
}

\begin{abstract}
Legal Policy is a new study and part of constitutional law (Staatrecht). Legal Policy is derived from two disciplines which are the Science of Law and the Philosophy of Law. Thus, it is not an intersection between the science of Law and Politics. Legal Policy operates on an empiricallyfunctional level using the teleological-constructive method. This implies that politics is in the sense of ethics and the techniques of forming law (rechtsvorming) and law discovery (rechtsvinding). From the ontological and epistemological aspects, Legal Policy has a very strong root to be included in the science of law because its core is laws of legislation in various forms and levels. Legal Policy provides an academic basis for the process of formation and discovery which is in line with welfare, circumstances, culture, and existing values in society.
\end{abstract}

Keywords: legal policy, rechtvinding, rechtsvorming, taxonomy

\begin{abstract}
Abstrak
Politik Hukum (Rechtspolitiek) adalah kajian yang relatif baru dan merupakan bagian dari disiplin Ilmu Hukum Tata Negara (Staatrecht). Politik Hukum terbentuk dari dua disiplin hukum yaitu Ilmu Hukum dan Filsafat Hukum dan bukan merupakan intersection antara Ilmu Hukum dan Ilmu Politik. Politik Hukum berbicara pada tataran yang empiris-fungsional dengan menggunakan metode teleologis-konstruktif. Hal ini mengandung pemahaman bahwa terminologi 'politik' dalam Politik Hukum bermakna sebagai etik dan teknik kegiatan pembentukan hukum (rechtsvorming) dan penemuan hukum (rechtsvinding). Dari aspek ontologis dan epistimologis Politik Hukum memiliki akar yang sangat kuat untuk dimasukan ke dalam studi Ilmu Hukum karena kenyataannya core problem dari studi Politik Hukum adalah hukum (peraturan perundang-undangan dalam berbagai bentuk dan levelnya). Artinya, sebagai sebuah disiplin hukum, Politik Hukum memberikan landasan akademis terhadap proses pembentukan dan penemuan hukum yang lebih sesuai dengan konteks kesejahterahan, situasi dan kondisi, kultur, nilai-nilai yang berkembang di masyarakat.
\end{abstract}

Kata kunci: politik hukum, rechtsvinding, rechtsvorming, taxonomi

\section{Introduction}

The term Legal Policy was firstly introduced in Indonesia by Lemaire in 1955 in his work 'Het Recht in Indonesia' (Indonesian Law). The study of this discipline is closely related to the study of government policy in the field of legal development. Efforts on legal development are necessary to maximize its noble role and function as a guide of conduct in living together. ${ }^{1}$

Basically, Legal Policy is a relatively new study either in Political studies or Law studies.

Retno Saraswati, "Arah Politik Hukum Pengaturan Desa ke Depan (Ius Constituendum)", Jurnal Masalah- Masalah Hukum, Vol. 43 Number. 3, July 2014, p. 316.
The existing argument that the study could fit in both sciences remains arguable among both experts particularly dealing with its position in the taxonomy of science. In regards to this, the experts of Law Studies agree that the study of Legal Policy within Law Studies is included in the scope of Constitutional Law or in Dutch known as Gesetzgebungswissenchaft which is part of Constitutional Law Studies (Staatrecht). ${ }^{2}$

Conceptually, the domain of the discipline of Legal Policy does not stop at the philo-

M. Ilham F. Putuhena, “Politik Hukum Perundang- undangan: Mempertegas Reformasi Legislasi yang Progresif", Jurnal Rechtsvinding Media Pembinaan Hukum Nasional, Vol. 2 Number 3, December 2013, p. 385. 
sophical and theoretical level only, but up to normative operations as well. In the philosophical-theoretical dimension, legal policy is a parameter of value for the implementation of development and legal coaching in the field. As an operative normative dimension, legal policy more focuses on reflecting the will of the authorities on the desired social order. ${ }^{3}$

Legal Policy plays pivotal role in the process of making, the formulation of legal substance and law enforcement. In Indonesian perspective, legal policy is significant to ensure the implementation of good governance for Indonesia's national development goals.

In conceptual and theoretical framework, the study of Legal Policy will include three (3) key issues namely: (1) regarding the law to be enacted and which will not be enforced in line with the direction of the state's objectives; (2) political background and other social sub-systems behind the enactment of new legal products; and (3) law enforcement issues resulting from the implementation of Legal Policy. ${ }^{4}$ Legal Policy Studies can be classified as one of the auxiliary sciences (hulpwetenschap) that can be used as a tool of analysis to explain comprehensively how the processes of legal formation.

In a democratic legal state like Indonesia, the development of a nation cannot be separated from the people ideals; to build a fair and civilized nation as implied in the Preamble of the 1945 Constitution of the Republic of Indonesia (NRI) namely the establishment of a state of democratic law is strong, fair and prosperous. This is the main purpose of our National Legal Policy, namely the law that protects and gives prosperity to the people.

As a new sub study, the attempt to clarify and reinforce how the definition of Legal Policy is etymologically and terminologically

3 Marzuki Wahid, “Konfigurasi Politik Hukum Islam di Indonesia; Studi Tentang Pengaruh Politik Hukum Orde Baru Terhadap Kompilasi Hukum Islam", Mimbar Studi, Number. 2 Year XXII, January-April 1999, p. 104-105.

4 Moh. Mahfud MD, 2010, Membangun Politik Hukum, Menegakkan Konstitusi, Jakarta: PT Raja Grafindo Persada, p. 6. crucial to determine its position in the taxonomy (tassein) of science. The position determination in the classification of science and comprehending how the scope of the study becomes focal for legal policy development and other potential branches of science emerged from the Legal Policy. Furthermore, the relation between Legal Policy and Pancasila as a rechtidee and the 1945 Constitution of the Republic of Indonesia is also important to be clarified to provide more guideline on the direction of legal policy. A century ago, Gebroeders Belinfante, a law expert of the Netherlands, once asserted that the object of Constitutional Law also includes matters outside the positive law. Apparently, Belinfante opinion is the basis of Legal Policy Categorization in the Legal Scientific branch in Indonesia today. ${ }^{5}$

\section{Discussion}

\section{The Meaning of Legal Policy in Etymology}

Etymologically, Legal Policy is a translation of the Dutch legal term rechtspolitiek. ${ }^{6}$ The word rechts in Indonesian means law, while the word politiek contains beleid meaning which means policy. ${ }^{7}$ The term rechtspolitiek should not be juxtaposed with politiekrecht or Legal Policy which according to Hence van Maarseveen, replace the term Constitutional Law. ${ }^{8}$

The term 'policy' is often mistakenly treated as 'wisdom'. In fact, both terms have very different meaning conceptually. G. Pringgodigdo 9 differentiates the terms 'wisdom' (policy, beleid) from 'policy' (wisdom, wijsheid). According to him, wisdom is the series of action or activity that are planned in legal sector in or-

5 Ibid., p. 3.

6 Eddy Asnawi in Kartono, "Politik Hukum Judicial Review di Indonesia”, Jurnal Dinamika Hukum, Vol. 11, February 2011, p. 17.

7 Derita Prapti Rahayu, “Aktualisasi Pancasila Sebagai Landasan Politik Hukum Indonesia”, Yustisia, Vol. 4 Issue. 1, January-April 2015, p. 193.

8 Sri Soemantri, “Undang-Undang Dasar 1945, Kedudukan dan Artinya dalam kehidupan Bernegara", Jurnal Demokrasi dan HAM, Vol. 1 Number. 4, SeptemberNovember 2001, p. 43.

9 Imam Syaukani and A. Ahsin Thohari,2008, Dasar-Dasar Politik Hukum, Jakarta: PT Raja Grafindo Persada, p. 24-25. 
der to achieve the goals. On the other hand, policy is instant decision like making written or spoken decision based on discretionary power, freies ermessen. Furthermore, the definition of wisdom basically needs further considerations, meanwhile policy only covers the regulations inside. ${ }^{10}$ Therefore, the writer concludes that etymological point of view of Legal Policy is legal wisdom. The view of the writer is exactly different from Moh. Mahfud MD's opinion which etymologically defines that Legal Politics is legal policy.

\section{Definition of Legal Policy terminologically}

Describing the definition of Legal Policy terminologically is necessary for comprehensive understanding on the phrase Legal Policy. Padmo Wahyono ${ }^{11}$ terminologically defines Legal Policy as policy of state organizers about what the criteria to sentence something are. It relates to legal formation, legal implementation, and its enforcement. Besides, TM Radhie ${ }^{12}$ defines Legal Policy as the desire of state rulers regarding the valid law in their surrounding, and the direction of legal development.

By understanding those two definitions above, difference lies on the highlight of Legal Policy. Padmo Wahyono prefers to emphasize the law that wants to be achieved (ius constituendum) and the currently implemented positive law (ius constitutum). Due to the changing of ius constitutum into ius constituendum to accomodate social change, the series of activity needs to be conducted for determining ius constituendum including: first, describing the elements of iusconstitutum; second, explaining the elements of social change; third, comparing ius constitutum to the elements of social change to find problem in implementing ius constitutum; fourth, formulating problem; fifth, determining data to solve problem; sixth, analyzing data to find three alternatives in problem solving; Seventh, deciding filter to

10 I Wayan Suandi, "Eksistensi Kebijakan Publik dan Hukum dalam Penyelenggraan Pemerintahan Daerah", Jurnal Ilmiah Fakultas Ilmu Sosial dan ilmu Politik Vol. 1 Number. 1, 2010, p. 12.

11 Imam Syaukani and A. Ahsin Thohari, op.cit., p. 26.

12 Ibid., p. 27. choose one of the alternatives; and Eighth, drawing the conclusion which is ius constituendum.

Another definition of Legal Policy is delivered by Soedarto, ${ }^{13}$ who states that Legal Policy is an effort to realize good regulations in accordance with circumstances at particular time. This definition shows that conceptual framework is required done by legislative to formulate appropriate regulation. On the other hand, Satjipto Rahardjo ${ }^{14}$ defines Legal Policy as the action to choose certain social purpose and the steps applied to achieve the purpose. Law must continuously make adjustment with the social purpose. Therefore, Legal Policy should be directed to ius constituendum.

Both opinions are different in emphasis. Soedarto points out formulating good regulation at particular time (ius constitutum) while Satjipto Rahardjo highlights an effort to choose social period and adjusting law with the social purposes (ius constituendum). The development of nation legal system must pay attention on the concept of legal thinking either ius constitutum or ius constituendum for predictable outcome in developing national legal system. It is a must to use valid positive law as consideration and reference for the development of legal aspects harmonized by the development of society. ${ }^{15}$

Based on Indonesia's perspective, Abdul Hakim Garuda Nusantara ${ }^{16}$ also conveys definition of Legal Policy which will or have done nationally by Indonesian government that includes: first, legal development in terms of formulating and renewing materials in accordance with the social change; second, implementation of the given legal provisions including institution enforcement and the law enforcer coaching. Apart from the definition, Legal Policy covers process of formulating and renewing materials in accordance with the social change

13 Moh. Mahfud MD, op.cit., p.14.

14 Ibid.

15 Oksep Adhayanto, "Perkembangan Sistem Hukum Nasional”, Jurnal Ilmu Hukum, Vol. 4 No. 2, February - July 2014, p. 224.

16 Abdul Hakim Garuda Nusantara in Derita Prapti Rahayu, loc.cit. 
implemented by law enforcers. This definition is more complete than the previous ones since it is not only about the formulating and renewal but also up to the consistency in institution and law enforcer.

If we take a look thoroughly, the steps of national Legal Policy has actually been managed or set orderly. Every law begins from (and consistent with) purpose of country, Pancasila system of law, rule of law, and constitution. In order to preserve the consistency of those paradigm, it is necessarily believed to complete it with two law instruments those are: (1) Prolegnas which illustrates to achieve purpose of country in certain period must be made in form of bill (RUU) to explain purpose of country at particular time and as guidance in making Law; also (2) judicial review by Constitutional Court (MK) and Supreme Court (MA).

\section{Scope for Legal Policy Study}

Imam Syaukani and A. Ahsin Thohari ${ }^{17}$ stated that the scope for Legal Policy study covers things as follows: first, process of extracting value and aspiration developed in society; second, process of argumentation and formulation of those value and aspiration into drafting the Law; third, authorized organizers formulate and decide Legal Policy; fourth, law that consists of Legal Policy; fifth, factors that influence and determine Legal Policy; and sixth, implementation of Law.

Factors that influence Legal Policy is not solely decided by what is intended nor the lawmakers, practitioner or theorists. Rather, it is decided by the fact and law development in other countries and international law development. The dynamics of international politics and have influence on national law cannot be set out to our national Legal Policy.

Law is the product of politics that leads to hypothetical decision that certain political configuration will bring forth certain character

17 Imam Syaukani dan A. Ahsin Thohari, Dasar...op.cit., p. 51-52. legal products. ${ }^{18}$ Related to statements above, Moh. Mahfud MD, ${ }^{19}$ stated that the character of legal product is largely determined by political configuration at that time, whether that is democratic or authoritarian. Democratic political configuration is a structure of political system opening up the opportunity for people to completely and actively participate to decide public policy. Furthermore, authoritarian political configuration is a structure of political system which allows country to play active role and take almost every initiative in making policy. It is marked by the urge elite power to force unity, removal of open opposition, leader of country's dominance to decide policy and dominance political power of elite which is everlasting, and the doctrine that justifies the formation of power concentration.

To know whether the political configuretion is authoritarian or democratic and whether the character of legal product is responsive or conservative, these benchmarks can be used such as: first, political configuration includes party system and the role of representative, executive and freedom of press; and second, character of legal product includes process of making law, function of law and the authority of interpretation.

Further explanation by Moh. Mahfud MD ${ }^{20}$ shows that responsive legal product is a legal product that reflects a sense of justice and fulfills people's expectations. Since there is the purpose and people's expectations so law has socio-political dynamics in its making. ${ }^{21}$

Then, conservative/orthodox/elitist legal product is a legal product that essentially reflects the social vision of elite politics and the will of government that is positivist-instrumentalist; it is a tool for ideology implementer and

18 Putera Astomo, “Pembentukan Undang-undang dalam Rangka Pembaharuan Hukum Nasional di Era Demokrasi”, Jurnal Konstitusi, Vol. 11 Issue. 3, September 2014, p. 587.

19 Moh. Mahfud MD, op.cit., p. 24-25.

20 Ibid., p. 25-26.

21 Anna Triningsih, "Politik Hukum Pengujian Peraturan Perundang-undangan dalam Penyelenggaraan Negara", Jurnal Konstitusi, Vol. 13 Number 1, March 2015, p. 127. 
country program. Process of making responsive legal product invites as many as people through social groups and individual in society. Meanwhile process of making conservative/orthodox/elitist legal product is centralized which means there is a dominance by country institution especially the executive power.

Basically, Law is a political product which views law as a formalization or crystallization of interrelated political wills. As a political process, formulating legislation cannot be separated from public participation to accommodate stakeholders interest. Public participation is focal in political legislation. Lothar Gundling quoted by Yuliandri22 says that four reasons for the importance of community participation in the policy preparation are: first, providing information to the government; secondly, increasing people's willingness to accept the decision; third, assist the protection of law; and fourth, democratizing decision-making. Related to public participation and the representation system, Koesnadi Hardjasoemantri ${ }^{23}$ argues that: first, a representative democracy system is one of a form of democracy and it is not the only one; second, representative system does not violate direct democracy; and third, citizens do not make decisions, they participate in the stages of preparation of decision-making only.

People's aspirations cannot be obstructed without going through fair aggregation. The history teaches us that if democratic aspirations are unfairly hindered then the aspiration will make its own way; it can be in the form of civil disobedience, demonstration to street justice though.

Public participation is also required in formulating legislation as stipulated in Law number 12 Year 2011 on the Establishment of Legislation, especially in article 96 in Chapter $\mathrm{XI}$ on community participation. As the implementation of the provisions, then it is embodi-

22 Yuliandri, 2010, Asas-asas Pembetukan Peraturan Perundang-undangan yang Baik, Gagasan Pembentukan Undang - Undang Berkelanjutan, Jakarta: Rajawali Pers, p. 187.

23 Widia Edorita, "Peran Serta Masyarakat terhadap Lingkungan Menurut UU No.32 Tahun 2009 Tentang Perlindungan dan Pengelolaan Lingkungan Hidup", Jurnal Ilmu Hukum Vol. 4 Number. 1 February 2014, p. 120. ed in article 208-210 in second part on Public Participation in House of Representatives Regulation no. 1/DPR RI/1/2009-2010 on order.

\section{Legal Policy in Taxonomy}

In order to comprehend Legal Policy, a fundamental analysis of the position of this discipline in the structure of the Scientific Tree of Law Sciences is required. From an ontological historical perspective, Legal Policy was born because of a complex problem polarization in society after the era of modernization in Indonesia. This prompted technocrats, scholars of Law Science to seek new theses in institutions of public law, administrative law and social-economic law to address the challenges of multi-dimensional life problems.

An issue of the Legal Policy position in realm of science also emerged and provoked debate. Some experts place Legal Policy as part of Law Science while others place it in Political Science. From ontological and etymological aspects, Legal Policy has very strong roots to be included into law studies because in fact the core problem of Legal Policy studies is law (legislation of various forms and levels). ${ }^{24}$ Purnadi Purbacaraka and Soerjono Soekanto ${ }^{25}$ asserted that Legal Policy is part of law study which is formed from two legal disciplines namely Law Science and Law Philosophy. This view is clearly different from the existing view so far in which Legal Policy is a combination of intersection between Law and Political Science.

The second opinion is based on the fact that legal formation process (rechtsvorming) and legal discovery (rechtsvinding) is required to answer social problems both Law science and Law Philosophy and those must work together. Relying only on Law Philosophy results in an abstract and speculative law as philosophy characteristics. In contrast, relying only on Law Science will produce rigid law. These two disciplines of law must be used simultaneously and proportionally for their relatedness. Law science is intended as ways to achieve the goal

24 Imam Syaukani and A. Ahsin Thohari, op.cit., p. 36.

25 Ibid. 
while the Philosophy of Law is directed to the desired goal.

A mutualism process to achieve goals and expected goal will produce a Legal Policy. In contrast to law science (legal dogmatic and legal facts) which is theoretical-rational and theoretical empirical while Legal philosophy which is philosophical Law, Legal Policy talks about an empirically-functional level using the teleological-constructive method. ${ }^{26}$ This implies that politics is more in the sense of ethics and techniques of rechtsvorming and rechtvinding activities; moreover, it is more directed to see the extent to which established laws have benefits and movements in the process of desired community transformation.

When Legal Policy links to the practice of policy making and policy executing in the field of law, as a theory, it will be able to reveal policy evaluation, policy approximation and policy recommendation. The picture below will portray a clear position of Legal Policy in law disciplinary.

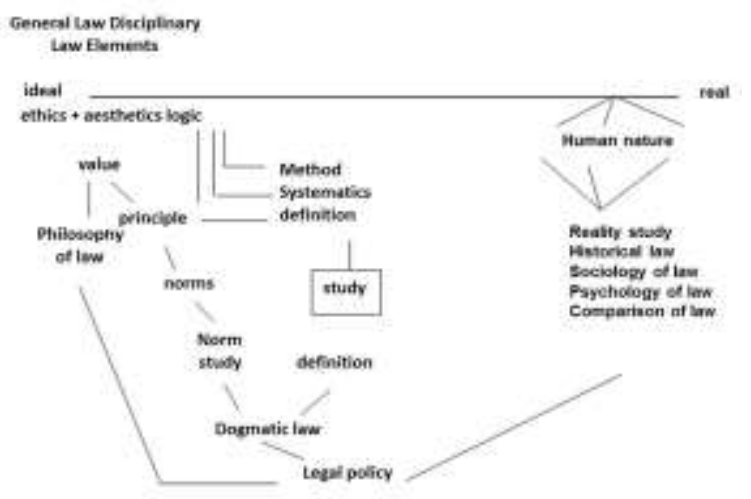

Picture 1.

Element of politics law discipline (Source: Imam Syaukani dan A. Ahsin Thohari, 2008)

Based on the picture above, law discipline has three types, they are law studies, law philosophy, and Legal Policy. After becoming a separate discipline, Legal Policy has its characteristics. Legal Policy in its relation to law formation and discovery is practical-functional with teleological-constructive elaboration method.

26 Ibid., p. 41.
It means, as a legal discipline, Legal Policy provides academic foundation to formation and discovery processes which is more suitable to prosperity context, situation and condition, culture, also developed values in society.

As consequences, ancient academic perspective has placed Legal Policy as a special law discipline which is important and influential in the formation process of particular law discipline (law of state, individual, wealth, family, inheritance, criminal) and law technology. As we can see in the following picture:

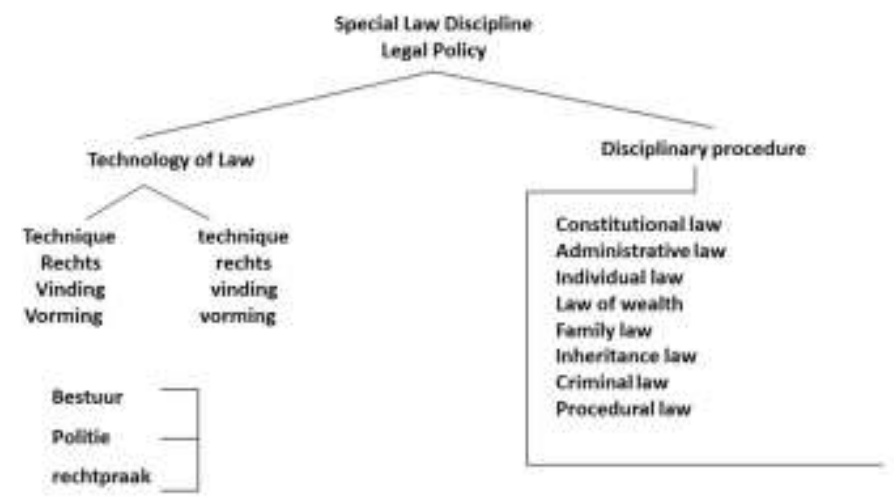

Picture 2.

Objects Influenced by Legal Policy

(Source: Imam Syaukani and A. Ahsin Thohari, 2008)

Not only consist of theoretical framework but also corresponds to its practical-functional characteristics, this law discipline is used to form regulation which originally becomes an authority of particular law discipline that formed (Legal Policy become a study of constitutional law science).

As prior explanation that Legal Policy is a basic policy of state organizer in field of law, which will and has been applied from values in society to realize intended state goal. The word "state organizer" and "intended goal" shall be necessarily observed by its meaning. State organizer is state institutions which given an authority by the constitution to conduct a government in particular state. Broadly speaking, the definition of state organizer is known 
as government included legislative, executive, judicatory authority and BPK/Indonesian Audit Board (in Indonesian context)

After Indonesia claimed their independence, the direction of law policy (law goal) must be suitable with staatsidee and rechtsidee embodied in Pancasila and Constitutional law of $1945 .{ }^{27}$ The direction of law policy emphasizes that Pancasila as staatsfundamentalnorm made a constitution and determine the content and form of any regulations under Pancasila which is hierarchically arranged. If the lower norm is against or unsuitable with Pancasila, it would be unconstitutional and illegal. Thus, the lower norm can be annulled and void by law.

In fact, whether we want to fill the law vacuum or not, we have to naturalize colonial laws which surely inconvenient with our ideology and constitution. Thus, it demands an action to do a positive changes of legacy law from Dutch such as Indische Staatsregeling (IS), Algemene Bepalingen van Wetgeving voor Indonesie $(A B)$, Burgerlijke Wetboek (BW), Wetboek van Koophandel (WvK), Wetboek van Strafrecht (WvS) historically made to fulfill colonial interest. The fact that some contents of the law is appropriate with values and norms in our society are adopted as long as no new laws.

Law goals have three elements namely justice, beneficial, and law certainty. If law formation more concerns on law certainty, the articles tend to be rigid. Thus, justice values expected by society are swapped and it is difficult to know its existence which affects beneficial loss. ${ }^{28}$

In the meantime, the state goals are protect the whole people of Indonesia and the entire homeland of Indonesia, promote general prosperity, develop the nation's intellectual life, and contribute to the implementation of a world order based on freedom, lasting peace and social justice (Preamble of constitutional

27 Heriyono Tardjono, “Reorientasi Politik Hukum Pembentuk Undang-undang di Indonesia", Jurnal Renaissance, Vol. 1 Number. 2, August 2016, p. 67.

28 Maryanto, "Urgensi pembaharuan Hukum Indonesia Berdasarka Nilai-nilai Pancasila”, Jurnal Hukum, Vol. XXV Number. 1 April 2011, p.429. law 1945). The goals in the preamble is then elaborated in detail through Articles in constitutional law and applied in form of law or regulation under the constitutional law. This is an undeniable argument that Legal Policy is part of constitutional law study.

\section{Conclusion}

Legal Policy then is a law policy which functions as a direction in building law to materialize state goals. From ontological and epistemological aspect, Legal Policy has strong root to be included in law science considering the core problem is regulations at any form and levels.

There is an agreement to make Pancasila as staatsidee and rechtsidee, so the direction of law policy (Legal Policy) must be actualized from values of God, Humanity and social (nationality, democracy, social justice) inscribed in Pancasila.

\section{References}

Adhayanto, Oksep. "Perkembangan Sistem Hukum Nasional". Jurnal Ilmu Hukum. Vol. 4 Number. 2. February-July 2015. Pp. 207-228;

Astomo, Putera. "Pembentukan Undang- undang dalam rangka Pembaharuan Hukum Nasional di Era Demokrasi”. Jurnal Konstitusi. Vol. 11 Number 3. September 2014. Pp. 577-599;

Kartono. "Politik Hukum Judicial Review di Indonesia". Jurnal Dinamika Hukum. Vol. 11. February 2011. Pp. 15-24. DOI: 10.20884/1.jdh.2011.11.Edsus.258;

Maryanto. "Urgensi Pembaharuan Hukum Indonesia Berdasarkan Nilai-Nilai Pancasila". Jurnal Hukum. Vol. XXV Number. 1. April 2011. Pp.420-438;

Marzuki, Wahid. "Konfigurasi Politik Hukum Islam di Indonesia; Studi Tentang Pengaruh Politik Hukum Orde Baru Terhadap Kompilasi Hukum Islam". Mimbar Studi. Number. 2 Year XXII. January-April 1999. Pp. 104-105;

Moh. Mahfud MD. 2010. Membangun Politik Hukum Menegakkan Konstitusi". Jakarta: PT. Raja Grafindo Persada; 
Putuhena, MIF. "Politik Hukum Perundang-undangan: Mempertegas Reformasi Legislasi yang Progresif". Jurnal Rechtsvinding Media Pembinaan Hukum Nasional. Vol. 2 Number 3. December 2013. Pp. 375-395;

Rahayu, Derita Prapti. "Aktualisasi Pancasila sebagai Landasan Politik Hukum Indonesia". Yustisia. Vol. 4 Number 1. January-April 2015. Pp. 190-202. DOI: 10. 20961/yustisia.v4i1.8634;

Saraswati, Retno. "Arah Politik Hukum Pengaturan Desa ke Depan (lus Constituendum)". Jurnal Masalah-Masalah Hukum. Vol. 43 Number 3. July 2014. Pp. 313-321. DOI: $10.14710 / \mathrm{mmh} .43 .3$. 2014. 313-321;

Soemantri, Sri. "Undang-Undang Dasar 1945, Kedudukan dan Artinya dalam Kehidupan Bernegara". Jurnal Demokrasi dan HAM. Vol. 1 No. 4. September-November 2001;

Suandi, I Wayan. "Eksistensi Kebijakan Publik dan Hukum dalam Penyelenggraan Pemerintahan Daerah". Jurnal Ilmiah Fakultas Ilmu Sosial dan ilmu Politik. Vol. 1 Number. 1. Year 2010. Pp. 11-19;

Syaukani, Imam dan Thohari, A. Ahsin. 2008. Dasar-Dasar Politik Hukum. Jakarta: PT. Raja Grafindo Persada.

Tardjono, Heriyono. "Reorientasi Politik Hukum Pembentuk Undang-undang di Indonesia". Jurnal Renaissance. Vol. 1 Number 2. August 2016. Pp. 61-74;

Triningsih, Anna. "Politik Hukum Pengujian Peraturan Perundang-undangan dalam Penyelenggaraan Negara". Jurnal Konstitusi. Vol. 13 Number 1. March 2016. Pp.124-144;

Widia, Edorita. "Peran Serta Masyarakat Terhadap Lingkungan Menurut UU No.32 Tahun 2009 Tentang Perlindungan Dan Pengelolaan Lingkungan Hidup". Jurnal Ilmu Hukum. Vol. 4 Number 1. February 2014. Pp. 118-132;

Yuliandri. 2010. Asas-Asas Pembentukan Peraturan Perundang-Undangan yang Baik, Gagasan Pembentukan Undang-Undang Berkelanjutan. Jakarta: Rajawali Pers. 